\title{
Arsenic Resistance and Prevalence of Arsenic Resistance Genes in Campylobacter jejuni and Campylobacter coli Isolated from Retail Meats
}

\author{
Aneesa Noormohamed and Mohamed K. Fakhr * \\ Department of Biological Science, The University of Tulsa, Tulsa, OK 74104, USA; \\ E-Mail: aneesa-noormohamed@utulsa.edu \\ * Author to whom correspondence should be addressed; E-Mail: Mohamed-fakhr@utulsa.edu; \\ Tel.: +1-918-631-2197; Fax: +1-918-631-2762.
}

Received: 17 May 2013; in revised form: 2 July 2013 / Accepted: 29 July 2013 /

Published: 7 August 2013

\begin{abstract}
Studies that investigate arsenic resistance in the foodborne bacterium Campylobacter are limited. A total of 552 Campylobacter isolates (281 Campylobacter jejuni and 271 Campylobacter coli) isolated from retail meat samples were subjected to arsenic resistance profiling using the following arsenic compounds: arsanilic acid (4-2,048 $\mu \mathrm{g} / \mathrm{mL})$, roxarsone $(4-2048 \mu \mathrm{g} / \mathrm{mL})$, arsenate $(16-8,192 \mu \mathrm{g} / \mathrm{mL})$ and arsenite $(4-2,048 \mu \mathrm{g} / \mathrm{mL})$. A total of 223 of these isolates (114 Campylobacter jejuni and 109 Campylobacter coli) were further analyzed for the presence of five arsenic resistance genes (arsP, arsR, ars $C, a c r 3$, and $\operatorname{arsB}$ ) by PCR. Most of the 552 Campylobacter isolates were able to survive at higher concentrations of arsanilic acid $(512-2,048 \mu \mathrm{g} / \mathrm{mL})$, roxarsone $(512-2,048 \mu \mathrm{g} / \mathrm{mL})$, and arsenate $(128-1,024 \mu \mathrm{g} / \mathrm{mL})$, but at lower concentrations for arsenite $(4-16 \mu \mathrm{g} / \mathrm{mL})$. Ninety seven percent of the isolates tested by PCR showed the presence of $\operatorname{ars} P$ and $\operatorname{ars} R$ genes. While $95 \%$ of the Campylobacter coli isolates contained a larger arsenic resistance operon that has all of the four genes ( $\operatorname{ars} P, \operatorname{ars} R, \operatorname{ars} C$ and $\operatorname{acr} 3$ ), $85 \%$ of the Campylobacter jejuni isolates carried the short operon (ars $P$, and $\operatorname{ars} R$ ). The presence of $\operatorname{ars} C$ and $a c r 3$ did not significantly increase arsenic resistance with the exception of conferring resistance to higher concentrations of arsenate to some Campylobacter isolates. arsB was prevalent in $98 \%$ of the tested Campylobacter jejuni isolates, regardless of the presence or absence of $\operatorname{ars} C$ and $a c r 3$, but was completely absent in Campylobacter coli. To our knowledge, this is the first study to determine arsenic
\end{abstract}


resistance and the prevalence of arsenic resistance genes in such a large number of Campylobacter isolates.

Keywords: Campylobacter; arsenic resistance; $\operatorname{ars} P$; $\operatorname{arsR}$; $\operatorname{ars} C$; $\operatorname{acr} 3$; $\operatorname{arsB}$; arsenic operon; retail meats

\section{Introduction}

Recent studies reporting the presence of arsenic residues in chicken [1-3] have led to the voluntary stoppage of the sale of the most commonly used orgnoarsenical, roxarsone, produced by Alpharma, a subsidiary of Pfizer Inc. [4]. Resistance to arsenic has been linked to the use of arsenical compounds in the feed of poultry for pigmentation [5], growth promotion and weight gain [6-8] and for the treatment of parasites [5,7]. A recent study suggested that the role of roxarsone on growth promotion in chicken is through modifying the expression levels of some cell growth and energy metabolism associated genes [9]. Poultry manure contaminated with arsenic can contribute to an increase in the concentration of arsenic in the environment [10].

Although not as extensively studied as antimicrobial resistance, arsenic resistance in Campylobacter is beginning to garner attention. Few years ago, an arsenic resistance operon was identified in Campylobacter jejuni [11]. Another study has also shown the presence of a four-gene arsenic resistance operon in Campylobacter lari [12]. More recently, Shen et al. discussed the contribution of $\operatorname{ars} B$, a putative efflux transporter gene that is not part of the previously characterized operon, to arsenic resistance in Campylobacter jejuni [13]. Including the recent arsB study above, only three studies are currently available in which Campylobacter isolates mostly from retail poultry were screened for their arsenic resistances $[11,13,14]$. This might be due to the lack of data on the amounts of these substances in the feed or its impact on human health [6].

Although the arsenic resistance operon is found mostly in Gram negative organisms, it has been found in Gram positive organisms as well, and is thought to originate from Gram positive bacteria $[15,16]$. The arsenic resistance determinants can be found in the chromosome as in the case of Escherichia coli or on transmissible plasmids as in the case of Staphylococcus aureus $[15,17,18]$. Generally, arsenic resistance operons contain three to five genes [15,16]. The 3-gene system found on $E$. coli and $P$. aeruginosa chromosomes and on $S$. aureus plasmids contains ars $R$ (transcriptional repressor), $\operatorname{ars} B$ (arsenite permease), and $\operatorname{ars} C$ (arsenate reductase) [16-18]. The 5-gene system found on $E$. coli plasmids and A. multivorum plasmids contains arsR (arsenite inducible repressor), arsD (negative regulatory protein), ars $A$ (ATPase), $\operatorname{ars} B$ (asenite efflux pump), and $\operatorname{ars} C$ (arsenate reductase) which converts As (V) to As (III) [16]. A 4-gene system is also available such as the one found in Campylobacter jejuni, Campylobacter lari, B. subtilis, S. marsecens, and T. ferrooxidans [11,12,16,19,20]. The Campylobacter jejuni arsenic resistance operon has been sequenced and shown to contain two to four genes [11]. The four genes that have been identified are $\operatorname{ars} R$ (a transcriptional repressor), ars $P$ (a putative membrane permease), $\operatorname{ars} C$ (an arsenate reductase), and acr3 (an efflux protein).

The aim of the present study was to determine the arsenic resistance and the prevalence of arsenic resistance genes in Campylobacter coli and Campylobacter jejuni isolated from retail meats purchased 
from the Tulsa (OK, USA) area grocery stores. To our knowledge, this is the first study to determine the prevalence of these genes in such a large number of isolates.

\section{Experimental Section}

\subsection{Bacterial Isolates}

A total of 552 Campylobacter isolates (281 Campylobacter jejuni and 271 Campylobacter coli) previously isolated from retail meat samples in our laboratory [21,22] were used for arsenic resistance profiling in this study. The isolates were from chicken $(n=130)$, turkey $(n=19)$, pork $(n=6)$, beef livers $(n=102)$, chicken livers $(n=272)$, and chicken gizzards $(n=23)$. All isolates were kept frozen at $-80{ }^{\circ} \mathrm{C}$ in Brucella broth (Becton Dickinson, Sparks, MD, USA) with $20 \%$ glycerol. A subset of 223 Campylobacter isolates out of the above mentioned 552 isolates was used for screening for the presence or absence of the tested arsenic resistance genes. The 223 Campylobacter isolates were representing one isolate out of each positive meat sample [21,22] and their meat sources were as follow: chicken $(n=49)$, turkey $(n=7)$, pork $(n=2)$, beef livers $(n=39)$, chicken livers $(n=113)$, and chicken gizzards $(n=13)$.

\subsection{Arsenic Resistance Screening}

The agar dilution plate method was used to screen for arsenic resisatnce. Isolates were grown on Mueller-Hinton (MH) agar (Difco, Sparks, MD, USA) supplemented with 5\% laked horse blood (Hemostat Laboratories, Dixon, CA, USA) and incubated for $48 \mathrm{~h}$ at $42{ }^{\circ} \mathrm{C}$ at microaerophilic conditions. Cultures were then added to Mueller-Hinton broth (Difco), adjusted to turbidity equal to a 0.5 McFarland standard, and inoculated onto 6-inch $\mathrm{MH}$ agar plates supplemented with 5\% defibrinated sheep blood and the arsenic compound at different concentrations (Table 1) using a 96-point replicator starting at the lowest concentration of each antimicrobial and working up. Since there are no published breakpoints for the arsenical compounds, we used the two published studies as a guide $[6,11]$ and we increased the range to ten different concentrations for each of the four tested arsenic compounds in our study (Table 1). The plates were incubated at $42{ }^{\circ} \mathrm{C}$ for $48 \mathrm{~h}$ under microaerophilic conditions. The plates were then read for growth or no growth and denoted as resistant or susceptible to this specific arsenic concentration, respectively.

Table 1. The arsenical compounds and their concentrations used for susceptibility testing.

\begin{tabular}{|c|c|c|c|c|c|c|c|c|c|c|}
\hline Arsenicals & $\begin{array}{l}\text { Conc. } 1 \\
(\mu \mathrm{g} / \mathrm{mL})\end{array}$ & $\begin{array}{l}\text { Conc. } 2 \\
(\mu \mathrm{g} / \mathrm{mL})\end{array}$ & $\begin{array}{l}\text { Conc. } 3 \\
(\mu \mathrm{g} / \mathrm{mL})\end{array}$ & $\begin{array}{l}\text { Conc. } 4 \\
(\mu \mathrm{g} / \mathrm{mL})\end{array}$ & $\begin{array}{l}\text { Conc. } 5 \\
(\mu \mathrm{g} / \mathrm{mL})\end{array}$ & $\begin{array}{l}\text { Conc. } 6 \\
(\mu \mathrm{g} / \mathrm{mL})\end{array}$ & $\begin{array}{l}\text { Conc. } 7 \\
(\mu \mathrm{g} / \mathrm{mL})\end{array}$ & $\begin{array}{l}\text { Conc. } 8 \\
(\mu \mathrm{g} / \mathrm{mL})\end{array}$ & $\begin{array}{l}\text { Conc. } 9 \\
(\mu \mathrm{g} / \mathrm{mL})\end{array}$ & $\begin{array}{l}\text { Conc. } 10 \\
(\mu \mathrm{g} / \mathrm{mL})\end{array}$ \\
\hline $\begin{array}{l}\text { Arsanilic } \\
\text { Acid }\end{array}$ & 4 & 8 & 16 & 32 & 64 & 128 & 256 & 512 & 1,024 & 2,048 \\
\hline Arsenate & 16 & 32 & 64 & 128 & 256 & 512 & 1,024 & 2,048 & 4,096 & 8,192 \\
\hline Arsenite & 4 & 8 & 16 & 32 & 64 & 128 & 256 & 512 & 1,024 & 2,048 \\
\hline Roxarsone & 4 & 8 & 16 & 32 & 64 & 128 & 256 & 512 & 1,024 & 2,048 \\
\hline
\end{tabular}




\subsection{DNA Extraction}

Bacterial DNA extracts used in polymerase chain reaction (PCR) were prepared from Campylobacter cultures using the single-cell lysing buffer (SCLB) method [23]. Isolates were struck to Mueller-Hinton agar ( $\mathrm{MH}$; Difco), and incubated at $42{ }^{\circ} \mathrm{C}$ for $48 \mathrm{~h}$ under microaerophilic conditions. One colony was picked from the plate and suspended in $40 \mu \mathrm{L}$ of SCLB solution in a $0.2 \mathrm{~mL}$ microtube. The SCLB solution contained $10 \mu \mathrm{L}$ of $5 \mathrm{mg} / \mathrm{mL}$ proteinase K (Amresco, Solon, OH, USA) and $1.0 \mathrm{~mL}$ of TE buffer (10 mM Tris-HCl (J. T. Baker, Phillipsburg, NJ, USA) and $1 \mathrm{mM}$ EDTA (Fisher, Fair Lawn, NJ, USA). The cells were lysed by heating at $80{ }^{\circ} \mathrm{C}$ for $10 \mathrm{~min}$, followed by cooling to $55{ }^{\circ} \mathrm{C}$ for $10 \mathrm{~min}$, using a thermocycler (Eppendorf, Hamburg, Germany). The suspension was diluted 1:2 in sterile double distilled water and centrifuged in a microfuge at 14,000 rpm for $30 \mathrm{~s}$ to remove cellular debris. The supernatant was used as DNA template for PCR.

\subsection{PCR for Arsenic Genes}

The selected arsenic resistant isolates were tested for the presence of arsenic resistance genes and operons by a regular PCR reaction using the primers designed specifically for Campylobacter jejuni and Campylobacter coli (Figure 1). For ars $C$, the following primer pair sequence [11] was used, Forward 5'-ATGAAACTTGCATTTATTTGTATT-3', Reverse 5'-CTAACATGTAAAGTCCTTAAGAGAA-3'. For acr3, the following primer pair [11] was used, Forward 5'-ATGTTAGGTTTTATCGATAGAT-3', Reverse 5'-TCATGAGGCTTGATTCATTTTT-3'. Due to some variations in the DNA sequence particularly for arsR between Campylobacter jejuni and Campylobacter coli, the following newly designed PCR primer pair in this study was used to detect simultaneously the presence of both $\operatorname{ars} P$ and $\operatorname{ars} R$ genes in isolates of the two species, Forward 5'-AAAGCTATATTTTTAGGTGCTTTAACG-3', Reverse 5'-TAAATGTCTTGAAAGTCTTG-3'. To amplify the whole operon even in case of missing ars $C$ and $a c r 3$, the following primers were used, Forward for Campylobacter jejuni 5'-CATTCATTTTAGAGTTATTGCGTATAAAACATACT-3' [11], Forward for Campylobacter coli 5'-TAAATAGCACTACTTAAACAACAAATAGCCAAAC-3' (Designed in this study), Reverse for both Campylobacter jejuni and Campylobacter coli 5'-ATACCCAAAGAGCAAAGTTTTATATAATGTTTGA-3' (Designed in this study). For the arsB, the following newly published primer pair [13] was used to screen both species, Forward 5'-GGAATTTACCTATTTGGGTAT-3', Reverse 5'-ATATTAATGCCTTTTCTAGCC-3'. A schematic presentation of the arsenic operon genes and the location of their PCR primers are shown in Figure 1. The PCR was carried out in $25 \mu \mathrm{L}$ reactions. Each $25 \mu \mathrm{L}$ reaction contained $12.5 \mu \mathrm{L} \mathrm{Taq}$ Polymerase Master Mix (Qiagen Inc., Valencia, CA, USA), $3.5 \mu \mathrm{L}$ sterile water (Qiagen), $1 \mu \mathrm{L}$ (25 pmol) each primer (IDT, Coralville, IA, USA), and $3 \mu \mathrm{L}$ of template DNA. The cycling conditions were set as follows for the arsenic genes tested: $95{ }^{\circ} \mathrm{C}$ for $5 \mathrm{~min}, 95^{\circ} \mathrm{C}$ for $1 \mathrm{~min}, 50{ }^{\circ} \mathrm{C}$ for $1 \mathrm{~min}$, $72{ }^{\circ} \mathrm{C}$ for $1 \mathrm{~min}$, and $72{ }^{\circ} \mathrm{C}$ for $10 \mathrm{~min}$. Steps 2 through 4 were repeated for 30 cycles. For the arsenic operon amplification, the extension time was increased to 3 min instead of 1 minute for each of the 30 cycle. Once the cycles were complete, reactions were held at $4{ }^{\circ} \mathrm{C}$ until gel electrophoresis. Ten microliters of PCR product was subjected to horizontal electrophoresis in a $1 \%$ agarose gel in $1 \mathrm{X}$ Tris-acetate-EDTA (TAE) buffer. A $1 \mathrm{~kb}$ plus ladder (Bioneer, Alameda, CA, USA) was used as the 
molecular marker. Gels were viewed and recorded by ultraviolet transillumination, using a UV imager. The expected amplicon sizes were $945 \mathrm{bp}$ for $\operatorname{ars} P / R, 423 \mathrm{bp}$ for $\operatorname{ars} C, 1044 \mathrm{bp}$ for $\operatorname{acr} 3$, and $1130 \mathrm{bp}$ for $\operatorname{ars} B$. Sterile water was used as the negative control. The DNA of few amplicons was sequenced in house to assure specificity.

Figure 1. A schematic diagram of the arsenic operon genes and the location of the PCR primers used for amplification. $C$ Op F (Campylobacter coli operon forward primer), J Op $\mathrm{F}$ (Campylobacter jejuni operon forward primer), J/C Op R (Both species operon reverse primer), $P / R \mathrm{~F}$ (arsP/ars $R$ forward primer), $P / R \mathrm{R}$ (ars $P / \operatorname{ars} R$ reverse primer), $C \mathrm{~F}$ (ars $C$ forward primer), $C \mathrm{R}$ ( $\operatorname{ars} C$ reverse primer), acr $\mathrm{F}$ ( $\operatorname{ccr} 3$ forward primer), and $a c r 3 \mathrm{R}$ (acr3 reverse primer).

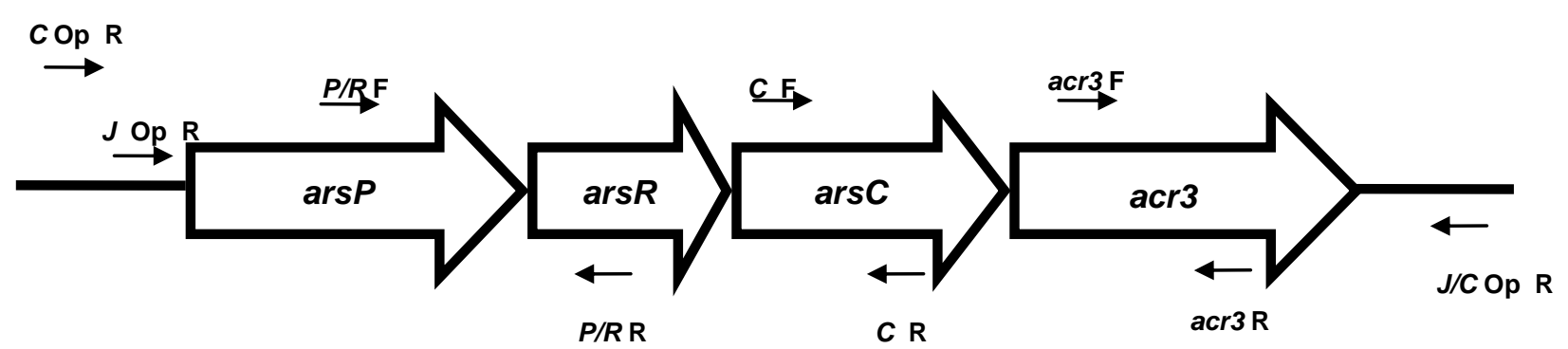

\section{Results and Discussion}

\subsection{Arsenic Resistance Screening}

Studies on arsenic resistance in Campylobacter species are limited in the literature $[6,11,12]$. In this study, a total of 552 Campylobacter isolates (281 Campylobacter jejuni and 271 Campylobacter coli) isolated from retail meat samples were subjected to arsenic resistance profiling using the agar dilution method to the following arsenic compounds: arsanilic acid $(4-2,048 \mu \mathrm{g} / \mathrm{mL})$, roxarsone $(4-2,048 \mu \mathrm{g} / \mathrm{mL})$, arsenate $(16-8,192 \mu \mathrm{g} / \mathrm{mL})$ and arsenite $(4-2,048 \mu \mathrm{g} / \mathrm{mL})$. The 10 different concentrations tested for each arsenic compound is listed in details in Table 1. The isolates were from chicken $(n=130)$, turkey $(n=19)$, pork $(n=6)$, beef livers $(n=102)$, chicken livers $(n=272)$, and chicken gizzards $(n=23)$. As shown in Table 2, most of the 552 Campylobacter isolates were able to survive at higher concentrations of arsanilic acid $(512-2,048 \mu \mathrm{g} / \mathrm{mL})$, roxarsone $(512-2,048 \mu \mathrm{g} / \mathrm{mL})$, medium concentrations of arsenate $(128-1,024 \mu \mathrm{g} / \mathrm{mL})$, but at lower concentrations for arsenite $(4-16 \mu \mathrm{g} / \mathrm{mL})$. It is apparent from the results above that the Campylobacter isolates screened in this study have a higher resistance to the organoarsenicals that is known to be used in production animal feeds (arsanilic acid and roxarsone). Using these compounds in feed can cause a selective pressure towards more resistant Campylobacter isolates. The isolates were not highly resistant to arsenite which is the most toxic by-product of the organoarsenicals. The high rates of resistance observed here are of some concern since it might be an indication of an extensive use of arsenic in the feed and raises a concern about the levels of this heavy metal in the retail meat consumed. The concern that retail meat products accumulate enough arsenical compounds that they may become carcinogenic and potentially affecting human health cannot be eliminated [14]. We hope that the voluntary stoppage of the sale of roxarsone 
by Alpharma will decrease such a risk to human health [4]. It is worth mentioning that our meat samples were collected before this voluntary stoppage of the sale of roxarsone.

Arsenic resistance to the four tested arsenic compounds did not vary much between the tested 281 Campylobacter jejuni and 271 Campylobacter coli isolates (Table 2, Figure 2). The only noticeable difference was that $15.5 \%$ of the Campylobacter coli isolates were resistant to higher concentrations of arsenate $(2,048-8,192 \mu \mathrm{g} / \mathrm{mL})$ where only $8.5 \%$ of Campylobacter jejuni isolates were resistant to the same concentration range.

Table 2. Percentage of Arsenic resistance of 281 Campylobacter jejuni and 271

Campylobacter coli isolates to ten concentrations of the four arsenic compounds tested.

Please refer to Table 1 for the detailed concentrations from 0 to 10.

\begin{tabular}{|c|c|c|c|c|c|c|c|c|}
\hline \multirow[b]{2}{*}{ Conc. } & \multicolumn{4}{|c|}{ Campylobacter coli } & \multicolumn{4}{|c|}{ Campylobacter jejuni } \\
\hline & $\begin{array}{l}\text { AA } \\
(\%)\end{array}$ & $\begin{array}{c}\operatorname{As}(\mathrm{V}) \\
(\%)\end{array}$ & $\begin{array}{c}\text { As(III) } \\
(\%)\end{array}$ & $\begin{array}{l}\text { Rox } \\
(\%)\end{array}$ & $\begin{array}{l}\text { AA } \\
(\%)\end{array}$ & $\begin{array}{c}\operatorname{As}(\mathrm{V}) \\
(\%)\end{array}$ & $\begin{array}{c}\operatorname{As}(\mathrm{III}) \\
(\%)\end{array}$ & $\begin{array}{l}\text { Rox } \\
(\%)\end{array}$ \\
\hline $\mathbf{0}-\mathbf{3}$ & $\begin{array}{c}1 / 271 \\
(0.4)\end{array}$ & $\begin{array}{l}56 / 271 \\
(20.7)\end{array}$ & $\begin{array}{c}256 / 271 \\
(94.5)\end{array}$ & $\begin{array}{c}0 / 271 \\
(0.0)\end{array}$ & $\begin{array}{l}1 / 281 \\
(0.4)\end{array}$ & $\begin{array}{c}61 / 281 \\
(21.7)\end{array}$ & $\begin{array}{c}272 / 281 \\
(96.8)\end{array}$ & $\begin{array}{c}0 / 281 \\
(0.0)\end{array}$ \\
\hline 4-7 & $\begin{array}{c}0 / 271 \\
(0.0)\end{array}$ & $\begin{array}{c}173 / 271 \\
(63.8)\end{array}$ & $\begin{array}{c}13 / 271 \\
(4.8)\end{array}$ & $\begin{array}{c}12 / 271 \\
(4.4)\end{array}$ & $\begin{array}{c}0 / 281 \\
(0.0)\end{array}$ & $\begin{array}{c}196 / 281 \\
(69.8)\end{array}$ & $\begin{array}{c}8 / 281 \\
(2.8)\end{array}$ & $\begin{array}{c}9 / 281 \\
(3.2)\end{array}$ \\
\hline 8-10 & $\begin{array}{c}270 / 271 \\
(99.6)\end{array}$ & $\begin{array}{l}42 / 271 \\
(15.5)\end{array}$ & $\begin{array}{c}2 / 271 \\
(0.7)\end{array}$ & $\begin{array}{c}259 / 271 \\
(95.6)\end{array}$ & $\begin{array}{c}280 / 281 \\
(99.6)\end{array}$ & $\begin{array}{c}24 / 281 \\
(8.5)\end{array}$ & $\begin{array}{l}1 / 281 \\
(0.4)\end{array}$ & $\begin{array}{c}272 / 281 \\
(96.8)\end{array}$ \\
\hline
\end{tabular}

Figure 2. Percentage of arsenic resistance of 281 Campylobacter jejuni (A) and 271 Campylobacter coli isolates (B) to ten concentrations of the four arsenic compounds tested. Please refer to Table 1 for the detailed concentrations from 0 to 10.

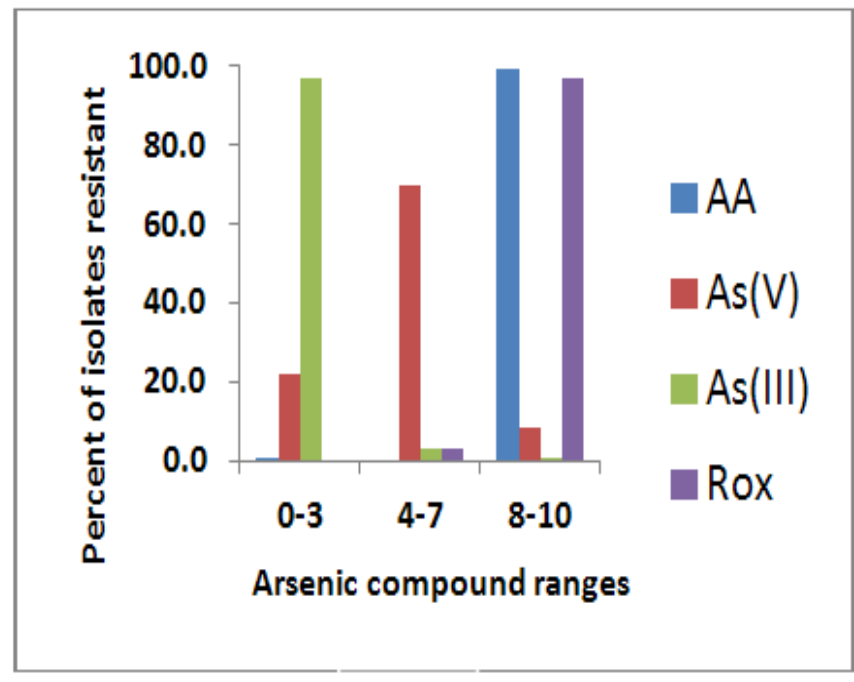

A

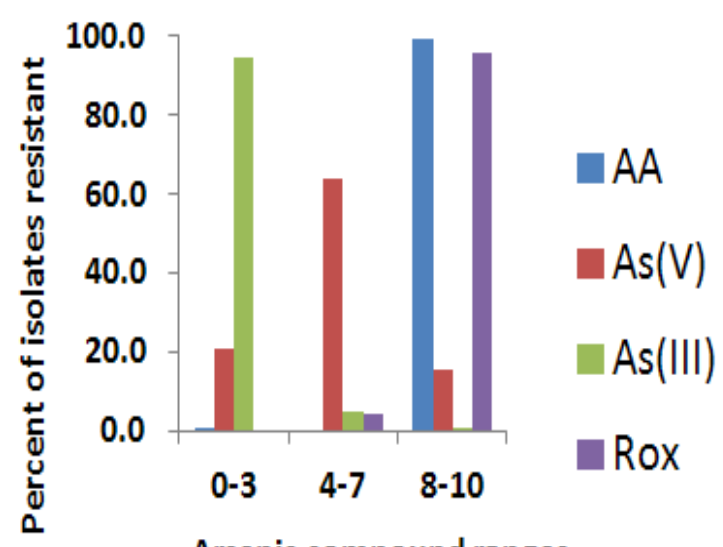

Arsenic compound ranges

\subsection{Arsenic Resistance Gene Screening}

A subset of 223 Campylobacter isolates (114 Campylobacter jejuni and 109 Campylobacter coli) were selected and further analyzed for the presence or absence of five arsenic resistance genes (ars $P$, 
arsR, ars $C$, acr3, and ars B) by PCR. The 223 Campylobacter isolates were selected to represent one isolate out of each positive retail meat sample. Ninety seven percent $(217 / 223)$ of the isolates tested by PCR showed the presence of arsR and arsP genes (Table 3). While 95\% (104/109) of the Campylobacter coli isolates contained a larger arsenic resistance operon that has all of the four genes (ars $P$, arsR, ars $C$ and acr3), only 15\% (17/114) of the Campylobacter jejuni isolates carried the large operon (Table 3). In a previous study, the arsenic resistance operon was characterized in Campylobacter jejuni [11]. It was found to contain $\operatorname{ars} P, \operatorname{ars} R, \operatorname{ars} C$ and $\operatorname{acr} 3$ [11]. In some isolates though, the authors of the study found that only ars $R$ and $\operatorname{ars} P$ were detected and not the $\operatorname{ars} C$ and acr3 [11]. A more recent study that investigated the distribution of colonization and antimicrobial resistance genes in Campylobacter jejuni isolated from chicken reported $90 \%$ prevalence of arsR and $47 \%$ prevalence of $\operatorname{ars} C$ [24].

Table 3. Percentage of arsenic resistance genes present in 114 Campylobacter jejuni and 109 Campylobacter coli isolates.

\begin{tabular}{ccccc}
\hline \multirow{2}{*}{ Genes } & \multicolumn{2}{c}{ Campylobacter jejuni } & \multicolumn{2}{c}{ Campylobacter coli } \\
\cline { 2 - 5 } & Isolates & \% & Isolates & \% \\
\hline arsR & $108 / 114$ & 94.7 & $109 / 109$ & 100 \\
ars $P$ & $108 / 114$ & 94.7 & $109 / 109$ & 100 \\
ars $C$ & $17 / 114$ & 14.9 & $105 / 109$ & 96.3 \\
acr3 & $20 / 114$ & 17.5 & $104 / 109$ & 95.4 \\
arsB & $112 / 114$ & 98 & $0 / 109$ & 0 \\
\hline
\end{tabular}

Ninety eight percent (112/114) of the tested Campylobacter jejuni isolates showed the presence of arsB, while none of the 109 Campylobacter coli contained the gene (Table 3). Interestingly enough, the only two Campylobacter jejuni isolates that did not harbor $\operatorname{ars} B$ were also lacking $\operatorname{ars} C$ and $\operatorname{acr} 3$ and were resistant to roxarsone, arsenate, and arsanilic acid (data not shown). While these are only two isolates but the data might suggest that there is still another unexplored mechanism of arsenic resistance in Campylobacter other than arsB. One cannot completely rule out the possibility of the involvement of the cmeABC efflux pump in this regard but this needs to be verified by mutagenesis experiments. Shen et al. (2013) reported a broad distribution of arsB and acr3 in Campylobacter jejuni isolates of different sources and suggested that at least one of these two genes is required for adaptation of Campylobacter to arsenic rich niches [13]. The complete absence of arsB from our screened Campylobacter coli isolates and its presence in $98 \%$ of the Campylobacter jejuni isolates, even those harboring acr3, highlight the possibility of the presence of another mechanism in Campylobacter arsenic resistance that is yet to be characterized.

As shown in Table 4, the presence of $\operatorname{ars} C$ and $a c r 3$ (large operon) appears to be more prevalent in Campylobacter coli than Campylobacter jejuni isolates rather than in a particular meat source. Within the Campylobacter jejuni isolates the prevalence of arsC and acr3 was higher in turkey $60 \%$ (3/5), and chicken gizzards $60 \%(6 / 10)$ isolates (Table 4) compared to the average prevalence of these two genes (14.9\% and 17.5\%) from all meat sources tested (Table 3). As shown in Figure 3 and Table 4 and if not taking the species into consideration, the prevalence of $\operatorname{ars} C$ and $a c r 3$ (large operon) appears to be 
higher in the pork isolates $(100 \%)$ followed by chicken gizzards (69\%), beef livers $(67 \%)$, chicken livers $(61 \%)$, turkey $(57 \%)$, and finally chicken $(29 \%)$.

Figure 3. A histogram showing the percentage prevalence of arsenic resistance genes in 223 Campylobacter screened isolates according to the meat source type of these isolates.

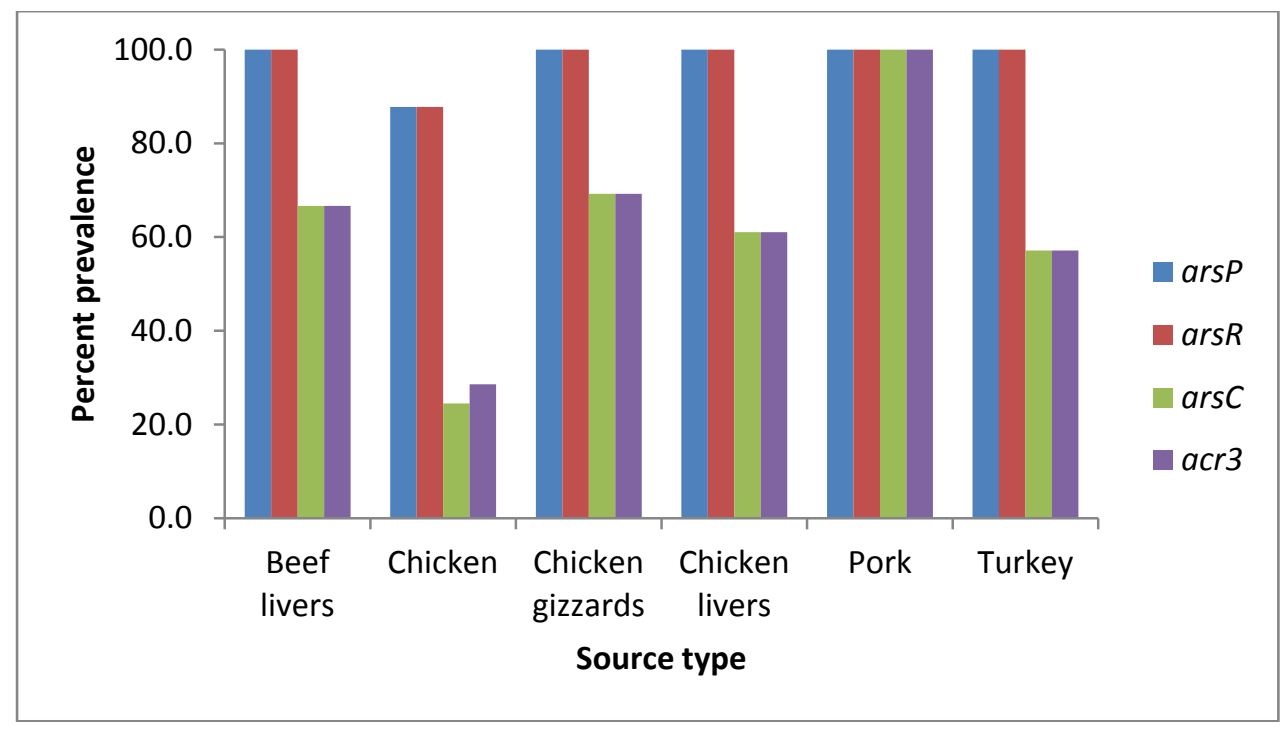

Table 4. Percentage of arsenic resistance genes present in 114 Campylobacter jejuni and 109 Campylobacter coli isolates according to the isolates meat source.

\begin{tabular}{|c|c|c|c|c|c|c|c|c|c|c|c|c|}
\hline \multirow{2}{*}{ Source } & \multicolumn{3}{|c|}{$\operatorname{ars} P * \mathrm{np} / \mathrm{n}(\%)$} & \multicolumn{3}{|c|}{$\operatorname{arsR} * \mathrm{np} / \mathrm{n}(\%)$} & \multicolumn{3}{|c|}{$\operatorname{ars} C * \mathrm{np} / \mathrm{n}(\%)$} & \multicolumn{3}{|c|}{$\operatorname{acr} 3 * \mathrm{np} / \mathrm{n}(\%)$} \\
\hline & C. jejuni & C. coli & Total & C. jejuni & C. coli & Total & C. jejuni & C. coli & Total & C. jejuni & C. coli & Total \\
\hline Beef & $13 / 13$ & $26 / 26$ & $39 / 39$ & $13 / 13$ & $26 / 26$ & $39 / 39$ & $0 / 13$ & $26 / 26$ & $26 / 39$ & $0 / 13$ & $26 / 26$ & $26 / 39$ \\
\hline livers & (100) & (100) & (100) & (100) & (100) & (100) & (0) & (100) & (66.7) & (0) & (100) & (66.7) \\
\hline \multirow[t]{2}{*}{ Chicken } & $34 / 40$ & 9/9 & $43 / 49$ & $34 / 40$ & $9 / 9$ & $43 / 49$ & $3 / 40$ & 9/9 & $12 / 49$ & $6 / 40$ & $8 / 9$ & $14 / 49$ \\
\hline & (85) & (100) & $(87.8)$ & (85) & (100) & (87.8) & (7.5) & (100) & (24.5) & (15) & (88.9) & (28.6) \\
\hline \multirow{2}{*}{$\begin{array}{l}\text { Chicken } \\
\text { gizzards }\end{array}$} & $10 / 10$ & $3 / 3$ & $13 / 13$ & $10 / 10$ & $3 / 3$ & $13 / 13$ & $6 / 10$ & $3 / 3$ & $9 / 13$ & $6 / 10$ & $3 / 3$ & $9 / 13$ \\
\hline & (100) & (100) & (100) & (100) & (100) & (100) & (60) & (100) & $(69.2)$ & (60) & (100) & $(69.2)$ \\
\hline \multirow{2}{*}{$\begin{array}{l}\text { Chicken } \\
\text { livers }\end{array}$} & $46 / 46$ & $67 / 67$ & $113 / 113$ & $46 / 46$ & $67 / 67$ & $113 / 11$ & $5 / 46$ & $64 / 67$ & $69 / 113$ & $5 / 46$ & $64 / 67$ & $69 / 113$ \\
\hline & (100) & (100) & $(100)$ & (100) & (100) & $3(100)$ & (10.9) & (95.5) & $(61.1)$ & (10.9) & (95.5) & $(61.1)$ \\
\hline \multirow[t]{2}{*}{ Pork } & $0 / 0$ & $2 / 2$ & $2 / 2$ & $0 / 0$ & $2 / 2$ & $2 / 2$ & $0 / 0$ & $2 / 2$ & $2 / 2$ & $0 / 0$ & $2 / 2$ & $2 / 2$ \\
\hline & (0) & (100) & (100) & (0) & (100) & (100) & (0) & (100) & (100) & (0) & (100) & (100) \\
\hline \multirow[t]{2}{*}{ Turkey } & $5 / 5$ & $2 / 2$ & $7 / 7$ & $5 / 5$ & $2 / 2$ & $7 / 7$ & $3 / 5$ & $1 / 2$ & $4 / 7$ & $3 / 5$ & $1 / 2$ & $4 / 7$ \\
\hline & (100) & (100) & (100) & (100) & (100) & (100) & (60) & (50) & $(57.1)$ & (60) & (50) & (57.1) \\
\hline
\end{tabular}

* np: number of positive isolates, $\mathrm{n}$ : total number of isolates screened.

\subsection{Correlation between Genotype and Arsenic Resistance}

As shown in Figure 1, arsenic resistance in Campylobacter is controlled by a four gene operon. ArsR is actually a negative regulator that binds to the promoter region of the operon and represses the transcription. Arsenite is believed to abolish the binding of arsR to the promoter region and transcription will occur [11]. In our study, the presence of $\operatorname{ars} C$ and $\operatorname{acr} 3$ genes in the large operon did not appear to significantly increase Campylobacter resistance to the tested arsenic compound (data not 
shown). The only noticeable difference was in regards to arsenate resistance where the only isolates that were able to grow at $(4,096-8,192 \mu \mathrm{g} / \mathrm{mL})$ were those harboring the ars $C$ and acr3 genes regardless of the Campylobacter species. So, having four genes did not seem to increase the resistance to arsenic compounds when compared to the isolates with two genes, except for allowing some isolates to resist higher arsenate concentrations. Having the $\operatorname{ars} C$ (an arsenate reductase) in the larger arsenic resistance operon might have a role in conferring such a higher resistance to arsenate. This can also explain our results above where the only noticeable difference between the two tested Campylobacter species was that $15.5 \%$ of the Campylobacter coli isolates were resistant to higher concentrations of arsenate $(2,048-80,192 \mu \mathrm{g} / \mathrm{mL})$ where only $8.5 \%$ of Campylobacter jejuni isolates were resistant to the same concentration range. The higher number of Campylobacter coli isolates resistance to high arsenate concentrations might be due to the fact that the majority of Campylobacter coli isolates harbor the larger arsenic resistance operon that carry the arsenate reductase gene ( $\operatorname{ars} C)$. Our finding is consistent with a previous study where they noticed that the presence of $\operatorname{ars} C$ and $\operatorname{acr} 3$ caused an increase in the resistance of the Campylobacter jejuni strains to arsenate and arsenite, even though they tested only 27 isolates in their study [11]. As shown in Figure 4, it is clear from the dendrogram that the presence of the four gene operon did not significantly increase arsenic resistance with the exception of arsenate where some isolates showed resistance to higher concentrations to this compound indicated by darker boxes in the figure which support our discussion above regarding resistance to arsenate. Most of the turkey Campylobacter jejuni strains harboring the large operon showed higher resistance to arsenate (Figure 4). The presence of $\operatorname{ars} B$ did not seem to increase resistance to any of the four tested arsenic compound by Campylobacter jejuni isolates in our study (Data not shown) since it was present in $98 \%$ of those isolates despite their slight resistance variation. The complete absence of $\operatorname{ars} B$ from any of the screened Campylobacter coli isolates is very interesting. To rule out the possibility of using a non-specific primer, the published DNA sequence for arsB from Campylobacter jejuni was blasted against the Genbank database including microbial genomes and no homology was found to this gene in any Campylobacter coli genome sequence. This can encourage us to suggest that there are still other possible unexplored mechanisms in conferring arsenic resistance to Campylobacter. A possible role of the CmeABC efflux pump in this regard is currently under investigation in our laboratory.

\section{Conclusions}

In conclusion, arsenic resistance is prevalent in Campylobacter jejuni and Campylobacter coli isolated from retail meats and a larger resistance operon is more prevalent in the Campylobacter coli strains. The presence of the four gene operon did not significantly increase arsenic resistance compared to the two gene operon with the exception of conferring resistance to higher concentrations of arsenate to some Campylobacter isolates. The arsenic resistance gene, arsB was prevalent in $98 \%$ of the Campylobacter jejuni isolates but was completely absent in the Campylobacter coli ones. The higher resistance of Campylobacter isolates to arsenic compounds in this study is alarming and warrants the FDA to revisit the tolerance levels set for the use of roxarsone in feed. To our knowledge, this is the first study to determine arsenic resistance and the prevalence of arsenic resistance genes in such a large number of Campylobacter isolates. 
Figure 4. A dendrogram created using the BioNumerics software showing a simple comparison of a 48 representative isolates of the six different meat sources by species showing the type of arsenic resistance gene operon harbored and the anti-arsenic resistance profiles. The intensity of the shaded box is related to the arsenic concentration tolerated by the isolate. The darker the box the higher the concentration tolerated for each arsenic compound. Campylobacter jejuni are labeled with red squares and Campylobacter coli are labeled with green squares. The meat source is listed by each isolate code as chicken livers, chicken gizzards, chicken, beef livers, turkey, and pork. The four tested anti arsenic compounds are listed on the top of the dendrogram right after the screened arsenic resistance genes.

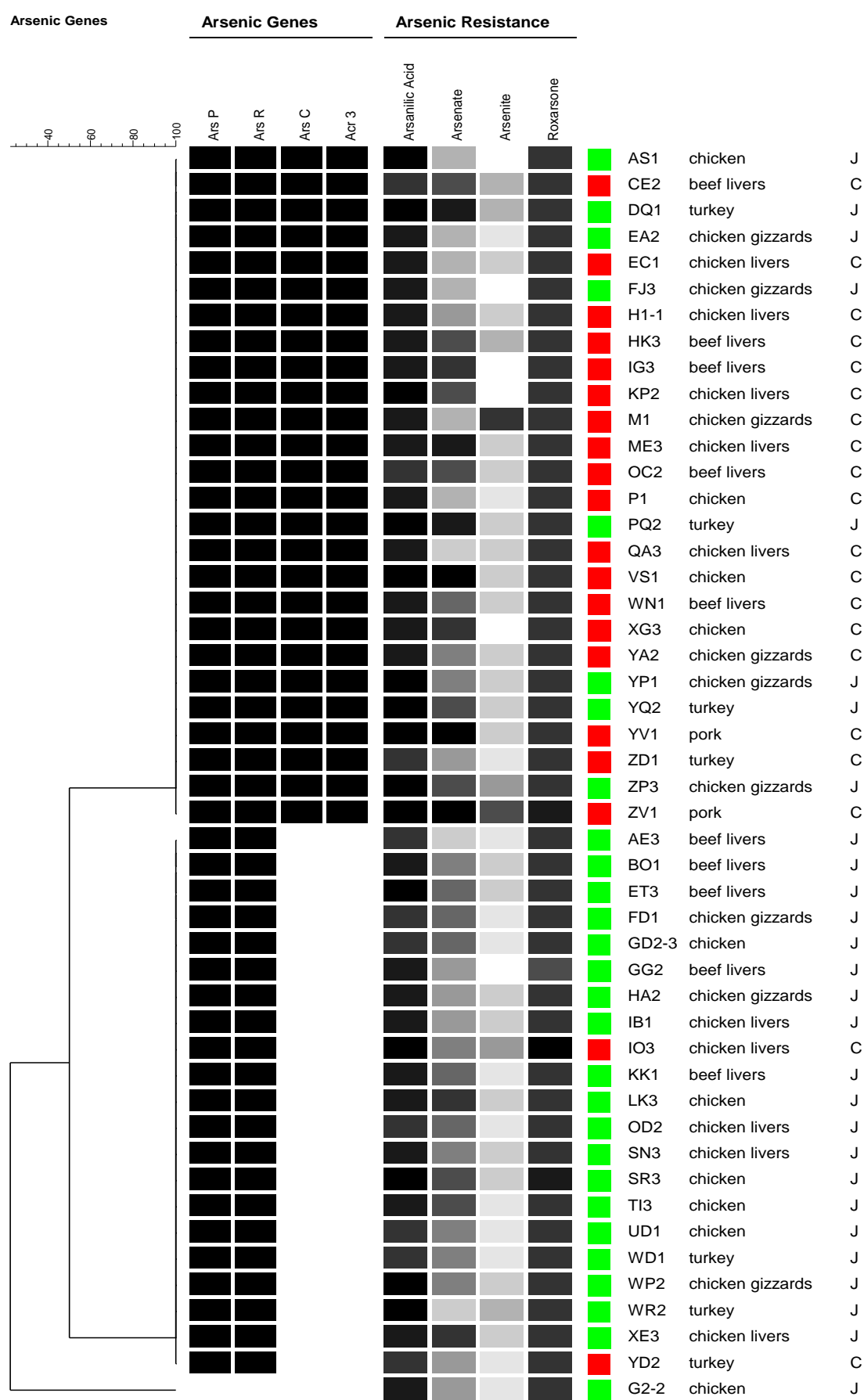




\section{Acknowledgments}

The authors would like to acknowledge financial support from the Graduate School of The University of Tulsa for granting Aneesa Noormohamed a Bellwether Doctoral Dissertation Fellowship.

\section{Conflict of Interest}

The authors declare no conflict of interest.

\section{References}

1. Lasky, T.; Sun, W.; Kadry, A.; Hoffman, M.K. Mean total arsenic concentrations in chicken 1989-2000 and estimated exposures for consumers of chicken. Environ. Health Perspect. 2004, 112, 18-21.

2. Wallinga, D. Playing Chicken: Avoiding Arsenic in Your Meat. The Institute of Agriculture and Trade Policy: Minneapolis, MN, USA. 2006. Available online: http://www.iatp.org/documents/ playing-chicken-avoiding-arsenic-in-your-meat (accessed on 5 May 2010).

3. Food and Drug Administration (FDA). 3-Nitro (Roxarsone) and Chicken. 2011. Available online: http://www.fda.gov/AnimalVeterinary/SafetyHealth/ProductSafetyInformation/ucm257540.htm (accessed on 29 August 2011).

4. Food and Drug Administration (FDA). FDA: Pfizer will Voluntarily Suspend Sale of Animal Drug 3-Nitro. 2011. Available online: http://www.fda.gov/NewsEvents/Newsroom/ PressAnnouncements/ucm258342.htm (accessed on 8 June 2011).

5. Kowalski, L.M.; Reid, W.M. Effects of roxarsone on pigmentation and coccidiosis in broilers. Poult. Sci. 2011, 54, 1544-1549.

6. Sapkota, A.R.; Lefferts, L.Y.; McKenzie, S.; Walker, P. What do we feed to food-production animals? A review of animal feed ingredients and their potential impacts on human health. Environ. Health Perspect. 2007, 115, 663-670.

7. Chapman, H.D.; Johnson, Z.B. Use of antibiotics and roxarsone in broiler chickens in the USA: Analysis for the years 1995 to 2000. Poult. Sci. 2002, 81, 356-364.

8. Waldroup, P.W.; Johnson, Z.B.; Helwig, H.M.; Ramsey, B.E.; Spencer, G.K. The response of broiler chickens to 3-nitro-4hydroxyphrnylarsonic acid (roxarson) in a series of broiler feeding trials. Nutr. Rep. Int. 1984, 30, 1079-1088.

9. Li, C.; Wang, X.; Wang, G.; Wu, C.; Li, N. Genome-wide expression analysis of roxarson-stimulated growth of broiler chickens (Gallus gallus). Comp. Biochem. Physiol. 2011, 6, 264-270, doi:10.1016/j.cbd.2011.05.003.

10. Garbarino, J.R.; Bednar, A.J.; Rutherford, D.W.; Beyer, R.S.; Wershaw, R.L. Environmental fate of roxartsone in poultry litter 1. Degradation of roxarsone during composting. Environ. Sci. Technol. 2003, 37, 1509-1514.

11. Wang, L.; Jeon, B.; Sahin, O.; Zhang, Q. Identification of an arsenic resistance and arsenic-sensing system in Campylobacter jejuni. Appl. Environ. Microbiol. 2009, 75, 5064-5073. 
12. Nakajima, T.; Hayashi, K.; Nagatomi, R.; Matsubara, K.; Moore, J.E.; Millar, B.C.; Matsuda, M. Molecular identification of an arsenic four-gene operon in Campylobacter lari. Folia Microbiol. 2012, 58, 253-260.

13. Shen, Z.; Han, J.; Wang, Y.; Sahin, O.; Zhang, Q. The contribution of ArsB to arsenic resistance in Campylobacter jejuni. PLoS One 2013, 8, doi:10.1371/journal.pone.0058894.

14. Sapkota, A.R.; Price, L.B.; Silbergeld, E.K.; Schwab, K.J. Arsenic resistance in Campylobacter spp. isolated from retail poultry products. Appl. Environ. Microbiol. 2006, 72, 3069-3071.

15. Ordonez, E.; Letek, M.; Valbeuna, N.; Gil, J.A.; Mateos, L.M. Analysis of genes involved in arsenic resistance in Corynebacterium glutamicum ATCC 13032. Appl. Environ. Microbiol. 2005, $71,6206-6215$.

16. Ryan, D.; Colleran, E. Arsenical resistance in the IncHI2 plasmids. Plasmid 2002, 47, 234-240.

17. Gotz, F.; Zabielski, J.; Philipson, L.; Lindberg, M. DNA homology between the arsenate resistance plasmid pSX267 from Staphylococcus xylosus and the penicillinase plasmid pI258 from Staphylococcus aureus. Plasmid 1983, 9, 126-137.

18. Cai, J.; Salmon, K.; DuBow, M.S. A chromosomal ars operon homologue of Pseudomonas aeruginosa confers increased resistance to arsenic and antimony in Escherichia coli. Microbiology 1998, 144, 2705-2713.

19. Butcher, B.G.; Deane, S.M.; Rawlings, D.E. The chromosomal arsenic resistance genes of Thiobacillus ferrooxidans have an unusual arrangement and confer increased arsenic and antimony resistance to Escherichia coli. Appl. Environ. Microbiol. 2000, 66, 1826-1833.

20. Sato, T.; Kobayashi, Y. The ars operon in the skin element of Bacillus subtilis confers resistance to arsenate and arsenite. J. Bacteriol. 1998, 180, 1655-1661.

21. Noormohamed, A.; Fakhr, M.K. Incidence and antimicrobial resistance profiling of Campylobacter in retail chicken livers and gizzards. Foodborne Pathog. Dis. 2012, 9, 617-624.

22. Noormohamed, A.; Fakhr, M.K. A higher prevalence rate of Campylobacter in retail beef livers compared to other beef and pork meat cuts. Int. J. Environ. Res. Public Health. 2013, 10, 2058-2068.

23. Marmur, J. A procedure for the isolation of deoxyribonucleic acid from microorganisms. J. Mol. Biol. 1961, 3, 208-218.

24. Thibodeau, A.; Fravalo, P.; Garneau, P.; Masson, L.; Laurent-lewandowski, S.; Quessy, S.; Harel, J.; letellier, A. Distribution of colonization and antimicrobial resistance genes in Campylobacter jejuni isolated from chicken. Foodborne Pathog. Dis. 2013, 10, 382-391.

(C) 2013 by the authors; licensee MDPI, Basel, Switzerland. This article is an open access article distributed under the terms and conditions of the Creative Commons Attribution license (http://creativecommons.org/licenses/by/3.0/). 